\title{
THE CURRENT ENTREPRENEURIAL CLIMATE IN RUSSIA
}

\author{
V.Starodubrovsky
}

The most serious obstacles in the way of Russia's economic development have to do with this country's underdeveloped market institutions and institutional environment, and an unfavorable entrepreneurial climate. The stagnation in the Russian national economy is indicative of the business community's evident lack of confidence in the future. The RF President has set the goal - to improve Russia's ranking on her ease of doing business from $120^{\text {th }}$ to $20^{\text {th }}$ in 2018 (Doing Business, the project launched by the International Finance Corporation and the World Bank). The Doing Business rating specifically ranks the economies in 10 areas of business regulation. The importance of removing excessive barriers is self-evident. But is this measure alone sufficient for forging confidence and making businesses alter their current behavior? An analysis of the existing negative features of the entrepreneurial climate, including those reflected in international rating systems, has revealed the true, much larger, scale of that problem. Stagnation has its roots primarily in the insufficient protection of property rights, rampant corruption, and the lack of a truly independent judicial system. By looking at Russia's current rankings, one may estimate the degree of this country's backwardness. Its economic potential thus can only be improved by means of a systemic upgrading of the existing institutional environment, starting with its most backward components.

The results of the past seven months are depressing. They vividly testify to a stable situation of economic stagnation in this country. Industrial growth has halted. The volumes of investment and cargo turnover are on the decline. Retail turnover continues to be somewhat on the rise, but at a very modest and sluggish pace over the last few years. Exports are dwindling in face of rising imports. Demand remains at a stable low level and fails to show any signs of growth. Production capacities continue to be underused. The rate of return is declining. Many companies with available funds prefer to keep their monies with banks as fixed deposits instead of investing in production development (fixed deposits representing the bulk of corporate deposits), because thus they can exist on interest - however low it may be. The monthly rate of net capital outflow from Russia is increasing. All this happens in spite of the fact that oil prices, while demonstrating some fluctuations, remain high.

The relatively steady decline of the growth rates of many basic economic indicators has been observed for a period of more than one-and-a-half years. The growth rate of GDP dropped from 5.1\% in Q4 2011 to $1.6 \%$ in Q1 and 1.2\% in Q2 2013, and that of goods and services in basic areas of economic activity - from $5.6 \%$ to $0.3 \%$ respectively on the whole over the first 7 months of 2013 (data for other indicators will also be presented for the period of the first 7 months); growth in industry from $5.7 \%$ in Q1 2011 to $0 \%$, including in the processing industries - from $10.6 \%$ to $-0.2 \%$; the growth rate of investments in fixed assets - from 14,8\% in Q4 2011 and $16.1 \%$ in Q1 2012 to $-0.7 \%$; the growth rate in the construction industry - from 9.1\% in Q4 2011 to $-0.3 \%$; the growth rate of rail freight turnover - from $9.1 \%$ in Q1 2011 to -2.9\%; and that of retail turnover - from 9\% in Q4 2011 to 3.8\%. Although it is true that the higher rates were recorded during the economic recovery period, the stable pace and the degree of their decline are, nevertheless, a self-evident fact.

Obviously, such a situation in the national economy and the ongoing trends are by no means conducive to boosting Russia's economic potential.

Given the current situation in the world economy, when Europe is still experiencing a recession, whilst the top international agencies are competing in downgrading their forecasts of future development in various regions across the globe, it is indeed very tempting to dismiss Russia's problems as part of the overall global situation. However, the global situation cannot altogether be dismissed, either. On the one hand, Europe absorbs approximately half of Russia's exports, while on the other, the danger of yet another crisis wave coming from abroad is very real. At the same time, so far (while the prices of hydrocarbons are not declining) the Russian economy has not yet been influenced by those factors that prevent the recovery of the European economy: high budget deficit and government debt. Besides, if we look at the developing countries, it will also become evident that their growth rates, although declining, still remain at levels far above our own growth rate. It means that, when faced with the same external conditions, they are capable of more efficiently utilizing their inner potential. It also means that we likewise possess a substantial inner potential.

Of course, as the situation in Western economies improves, some economic revival will also be likely in 
Russia. A number of economists are hoping for a better economic growth rate already in the second half year of 2013. The second half of last year was characterized by lower growth rates of the basic economic indicators than in the first half year, thus making less significant the per annum growth rate against which this year's indicators are set off. If one wishes to believe so, that level may be considered as an easy threshold to overcome. Some additional stimuli may arise in an event of the ruble's depreciation. Besides, the crop yield outlook this year us reasonably favorable, and this may become one positive factor influencing the results to be expected over the remaining part of the year 2013.

Nevertheless, whatever the effect of factors depending on the economic conjuncture may be, there undoubtedly exists a long-term trend of economic stagnation, with the inevitable conclusion that the difficulties being experienced by the Russian economy have some intrinsic causes. These have to do, first of all, with the institutional environment, as well as with the investment climate and the general entrepreneurial climate in this country. It would be wrong to describe it as simply unfavorable, because the existing situation in this respect is downright disastrous.

The state authority is not unaware of the acute problems associated with the existing entrepreneurial environment. It is not by chance that RF President Vladimir Putin set for Russia the task of to leap from her current $120^{\text {th }}$ (!) place in the World Bank and International Finance Corporation's Doing Business ranking to $20^{\text {th }}$ place in 2018 . In this connection it should be noted that this task is not about the ambitions to push Germany from its current 20th place - rather, it is about the importance to create in Russia the same conditions for doing business that currently exist in the developed countries with quite respectable rankings even somewhat below Germany's ranking. The experience of some countries is a vivid proof that fundamental economic progress may indeed be achieved after 7-9 years of diligent work.

There exist many systems for estimating and rating various parameters of the entrepreneurial climate applied by international organizations. These inevitably contain some biases. Some specialists have expressed their concerns that such ratings may to a certain degree be applied as a tool of political discrimination. However, they are based on well-tested methodologies and are elaborated by highly qualified end experienced expertas, are usually also rely on surveys conducted in relevant countries. Nevertheless, it must be taken into consideration that the results of such surveys may be influenced by personal 'level of demands' demonstrated by respondents who sometimes have elevated expectations with regard to the conditions for doing business, and so yield lower estimates than the respondents in countries with less favorable conditions. And vice versa. The highest caution is usually exercised by respondents in countries with authoritarian or totalitarian regimes. The rating of a certain country may vary even if its domestic business climate remains unchanged: it may go down the scale if the formerly backward countries begin to move forward, or go up if the situation in the former leader countries begins to deteriorate. Rating also depends on the actual number of countries, which can also vary from year to year. However, notwithstanding all these shortcomings, the rich experience accumulated over the years when the international comparison methodologies have been applied demonstrates that the comparative rankings of different countries offer sufficiently accurate results. We will now attempt to estimate the situation with institutional environment in Russia on the basis of a number of ratings that apply sufficiently comprehensive information on this country's institutions.

Let us begin with Doing Business. This index averages the country's percentile rankings on 10 areas, made up of a variety of indicators which describe the spheres of economic regulation with the most typical barriers set in the way of setting up and developing small and medium-sized businesses. The specificity of approach depends on exact targeting of the better and worse procedures conducive for doing business, and to estimate all positive and negative changes in these spheres. In each sphere, as a rule, the number of required procedures and/or documents is estimated, as well as the length and cost of formalization and registration procedures. The importance of improving this ranking is evident. According to Doing Business 2013 ${ }^{1}$, Russia since 2012 has moved from $118^{\text {th }}$ to $112^{\text {th }}$ among the total of 185 countries. Previously, her rating had been progressively worsening from being $78^{\text {th }}$ in 2006 to $123^{\text {rd }}$ in 2011 (all Doing Business 2012 rankings have been recalculated to reflect changes to the methodology and revisions of data due to new information, so any specific indices that it contains are comparable only with 2013, and not with the previous years, but the overall trends can be traced rather reliably on the basis of the formerly applied methodology). It is a good sign that this trend has been reversed, but Russia's ranking itself is no good at all. Another factor to be taken into consideration is that the information applied in the latest report was collected as of 1 July 2012 - that is, a year ago, and much has happened since then, and by no means all the developments have been favorable. In accordance with the estimates published in Doing Business 2013, Russia's best aspect of the business

1 http://www.doingbusiness.org/ /media/GIAWB/Doing\%20Business/Documents/Annual-Reports/English/DB13-full-report.pdf. 
regulatory environment is the effective commercial dispute resolution - an area where this country is already among the top 20, having mover from $13^{\text {th }}$ to $11^{\text {th }}$ place. However, the most impressive leap has been achieved in the sphere of taxation - from $105^{\text {th }}$ to $64^{\text {th }}$ place. This can probably be the result of lowered insurance contribution, which a year earlier had been steeply raised. Some progress can also be observed with regard to resolving insolvency (from $60^{\text {th }}$ to $53^{\text {rd }}$ place) and starting a business (although in this latter case Russia only moved from $105^{\text {th }}$ to $101^{\text {st }}$ place). While the ranking itself has changed little, the actual situation with regard to registering property has relatively improved (46 $6^{\text {th }}$ place). The ease of getting credit was downgraded (from 97th to 104th place), which is also true (and especially important from the point of view of business environment) of Russia's 'protecting investors' ranking (from $114^{\text {th }}$ to $117^{\text {th }}$ place). The worst results were achieved in the areas measured by 'getting electricity' (where Russia is $184^{\text {th }}$, followed only by Bangladesh), by "dealing with construction permits' (178 ${ }^{\text {th }}$ place), and by 'trading across borders (customs procedures etc. $-162^{\text {nd }}$ place).

There evidently exist serious obstacles in the way of improving Russia's current ranking. It a well-known fact that any bureaucratic barriers provide a good foundation and fertile ground for corruption. So, it is not difficult to imagine the scale of resistance to any improvements. Although Doing Business is an important ranking system, the question remains as to whether it truly encompasses all the basic features of the entrepreneurial climate determining the behavior of businesses. In other words, suppose that - no matter how difficult it may actually be - a country through applying a specific economic policy succeeds in upgrading its Doing Business ranking in a particular sphere, will then all its problems associated with an unfavorable business environment be removed, so that business could gain confidence in their future and accordingly alter their behavior?

There exist some other ratings that can help in providing answers to such question. Here we are going to look at several ranking systems that address the situation with regard to entrepreneurial environment. One of them is the Index of Economic Freedom developed by The Heritage Foundation - an independent organization that does not rely on any government support. The Index applies 10 benchmarks that gauge the economic success of 185 countries around the world. These benchmarks measure ten components of economic freedom in the spheres of economics and law, assigning a grade in each using a scale from 0 to 100 , where 100 represents the maximum freedom. The countries ranked from 80 to 100 are designated as truly "free" economies; those ranked from 70 to 79.9 are considered to be "mostly free"; from 60 to 69.9 moderately free; from 50 to 59.9 - "mostly unfree", and those ranked below 50 - "repressed". In the 2013 Index, ${ }^{1}$ predominantly information for the period from mid-2011 through mid-2012 was applied. The leader over many years had been Hong Kong, whose index hovers around and sometimes directly hits the 90 score. In 2013, the USA came $10^{\text {th }}$ (ranked 76.0); the UK $-14^{\text {th }}(74.8)$; Germany $-19^{\text {th }}(72.8)$; Japan $-24^{\text {th }}$ (71.8); and France $-62^{\text {th }}$ (64.1). Across the post-Soviet space, the leader is Estonia whose ranking is $13^{\text {th }}$ (75.3), and in addition to the Baltic states and Georgia - also Kazakhstan, in $68^{\text {th }}$ place (63.0).

Russia comes $139^{\text {th }}$, its Index of Economic Freedom being 51.1, which means that it belongs to the group of "mostly unfree" countries ${ }^{2}$. However, the Index rose on last year by 0.6 points. Its record high was observed in $2004-52.8$; in other words, over the past few years the situation has been worsening. The highest ranking has been achieved by the index of fiscal freedom -86.9 (38 ${ }^{\text {th }}$ spot), which has improved on last year by 4.4 points. This index is most strongly influenced by a low level of personal income tax, and its improvement is evidently associated with the lowering of the excessively high insurance contribution rate. It is followed by the index of trade freedom $-77.4\left(83^{\text {th }}\right.$ spot), which demonstrated the steepest climb since last year - by 9.2 points. This happened due to the relatively low average level of customs duties and Russia's accession to the WTO, although there still remain many non-tariff barriers that hinder free movement of goods and services. Next comes the index of business freedom, which implies first of all freedom from any direct interference on the part of the State, -69.2 (75 $5^{\text {th }}$ spot), with an increase on last year by 4.1 points. In this connection it is noteworthy that the business environment has improved only slightly, and bureaucratic regulation remains excessive, which makes any business decisions unreliable. The index of monetary freedom amounts to 66.7 (152 ${ }^{\text {th }}$ spot), having risen by 0.4 points. Russia's low overall ranking in view of the relatively good value of that index (above average) means that the majority of countries have higher indexes in this area. Here, the negative factors are the significant influence exerted by the government on the level of prices through numerous subsidies and a large number of state-owned companies. The index of government spending rose to 54.4, having improved by 5.8 points ( $117^{\text {th }}$ spot). A slight decline of this index relative to GDP is noted, as well as budget surplus (although this has been influenced by high oil

1 http://www.heritage.org/index/ranking

2 http://www.heritage.org/index/country/russia 
prices), and a low level of government debt. The index of labor freedom amounts to 52.6 (123 ${ }^{\text {th }}$ spot), having dropped significantly - by 10.9 points because, in the author's opinion, the outdated provisions of the labor code are obstacles to improving the level of employment and labor productivity. At the same time, it can be assumed that the real factor behind this trend is the government policy aimed at making workers keep their jobs, in order to bring down the unemployment growth rate and to ease the problems associated with high levels of unemployment. These are followed by the 'bottlenecks' in Russia's institutional environment: the index of financial freedom, which amounts to 30 $\left(130^{\text {th }}\right.$ spot) after having declined by 10 points due to the domination of government financial institutions, which narrow the niche available to private banks; the index of investment freedom, which remained unchanged since last year and amounts to $25\left(148^{\text {th }}\right.$ spot); the index of property rights -25 , likewise unchanged $\left(135^{\text {th }}\right.$ spot) due to the general weakness of the judicial system experiencing, among other things, also pressure from the government, with the resulting weak protection of property rights, including intellectual property; and, finally, the index of freedom from corruption which come last with the lowest value $24\left(140^{\text {th }}\right.$ spot), although it has increased by 3 points, probably due to the recent well-publicized major exposures of rampant corruption at the RF Ministry of Defense and some other institutions.

Thus, Russia's Index of Economic Freedom is also very low, and so it explicitly and adequately reveals the weakest features of our entrepreneurial climate, including those overlooked by Doing Business 2013.

The level of institutional development is analyzed in a number of ratings as one of the most important factors that cannot be overlooked when describing each of the spheres to be ranked in a given country. Its key role is recognized by The Global Innovation Index (GII), which acknowledges the need for a broad horizontal vision of innovation that is applicable to both developed and emerging economies, with the inclusion of indicators that go beyond the traditional measures of innovation. The importance of innovation is self-evident. The project was jointly launched in 2007 by Cornell University, the Business School for the World (INSEAD), and the World Intellectual Property Organization (WIPO, a specialized agency of the United Nations). The GII Report encompasses 142 countries and is composed of individual indicators (84 in total), being based on approximately 30 sources, including the results of surveys designed to determine the levels of five input pillars that capture the elements of the national economy that enable innovative activities. These factors are grouped so as to determine that innovation as a driver of economic growth and prosperity depending both on a country's individual innovation potential and the level of its actual utilization. The GII 2013 is calculated as the average of two sub-indices. The Innovation Input Sub-Index gauges elements of the national economy which embody innovative activities grouped in five pillars: (1) Institutions, (2) Human capital and research, (3) Infrastructure, (4) Market sophistication, and (5) Business sophistication. The Innovation Output Sub-Index captures actual evidence of innovation results, divided in two pillars: (6) Knowledge and technology outputs and (7) Creative outputs indicators. The Index is determined in absolute terms (in GII $2013,{ }^{1}$ Switzerland (66.59) tops the list), and so the other countries are ranked accordingly. Switzerland is followed by Sweden, the UK, The Netherlands, the USA, and Finland. Russia's ranking is $\mathbf{3 7 . 2}$, and it now comes $\mathbf{6 2 ^ { \text { nd } }}$, having lost 11 points since last year. It is ranked $72^{\text {th }}$ on the first Sub-Index and $52^{\text {th }}$ on the second Sub-Index, and stands $104^{\text {th }}$ on the Innovation Efficiency Ratio. Relatively more favorable are Russia's estimates with regard to human capital and research $-33^{\text {rd }}$, knowledge and technology outputs $-48^{\text {th }}$, infrastructure $-49^{\text {th }}$. However, as far as the 'institutions' pillar is concerned (the most relevant for us), Russia comes only $87^{\text {th }}$. The other rankings are as follows: political environment $-117^{\text {th }}$ (including the level of political stability $-117^{\text {th }}$, government performance $90^{\text {th }}$, freedom of the media $-119^{\text {th }}$ ), regulatory environment $-100^{\text {th }}$ (including regulation quality $-102^{\text {nd }}$, and rule of law $\left.-113^{\text {th }}\right)$. Somewhat better is the ranking of business environment $-55^{\text {th }}$. This may be found surprising, because a business environment is in principle determined by the entire existing system of institutions, which has lower ranking scores. However, in this context it is considered in a more narrow sense and encompasses only three factors: the simplicity of starting a business $\left(69^{\text {th }}\right)$; the simplicity of resolving insolvency $\left(49^{\text {th }}\right)$; and the simplicity of taxation procedures $\left(53^{\text {th }}\right)$. The ranking of market development is low $-74^{\text {th }}$. It is also strongly dependent on institutional factors. In terms of crediting Russia is ranked $116^{\text {th }}$, by the level of investor protection $-102^{\text {th }}$, by domestic competition intensity $-121^{\text {st }}$. Russia's creative outputs indicators are also very low - in this area, Russia is ranked $101^{\text {st }}$.

Innovative activities represent a key feature of a modern highly developed economy. The advantage of GII is its comprehensive approach based on multiple related factors. Its parameters graphically illustrate

1 http://www.globalinnovationindex.org/content. aspx?page=gii-full-report-2013\#pdfopener 
how Russia is prevented from moving forward by the poor state of her institutional environment.

However, from the point of view of the issues most relevant for us, the most informative indicator is The Global Competitiveness Index, determined in a yearly report under the auspices of the World Economic Forum (WEF) and based on statistical data and the results of Executive Opinion Survey conducted in 144 countries by its 150 partner organizations. The Index looks at 113 competitiveness variables, which are organized into twelve pillars, the first being Institutions (the parameters of their quality). The other pillars are as follows: Infrastructure; Macroeconomy; Health and Primary Education; Higher Education and Training; Market Efficiency; Labor Markets: Flexibility and Efficiency; Financial Markets: Sophistication and Openness; Technological Readiness; Market Size; Business Sophistication; and Innovation. The Index is calculated in absolute terms and applies a 1-7 score (from low to high competitiveness levels), by which the respondents in each country are asked to estimate each variable. The collected data are then weighted in accordance with the accepted methodology to obtain a cumulative index value, and each country is assigned its ranking score. The methodology clearly pursues the principle of maximum objectivity: the indexes and ranks are determined on the basis of statistics, and for most part - the outcomes of surveys. The specificity of the score applied in calculating the index (up to 7) means that its change by 0.1 points may push a given country up or down the list by several spots.

The Global Competitiveness Report 2012-2013 ${ }^{1}$ was released in 2012, and so the actual latest data, at best, refer to that year. For the fourth year in a row, Switzerland ranks as the most competitive country in the world with a score of 5.72, followed by Singapore and Finland. Germany comes $6^{\text {th }}$, the USA $-7^{\text {th }}$, Japan $10^{\text {th }}$ with a score of 5.4 .

Russia experienced its best situation shortly before the crisis (The Global Competitiveness Report 20082009), when her index was 4.3 , and it ranked $51^{\text {st }}$. However, already a year later Russia's index dropped to 4.15 , and the country moved to $63^{\text {rd }}$ place. Over the last three years, it continued its movement down the list to $67^{\text {th }}$ place, whilst the index remained practically unchanged - 4.2. Evidently, some of the previously more backward countries began to catch up and come ahead of Russia's score.

The specific factors and the impact of each pillar on competitiveness varies across countries, and the ratios between each country's index and its actual place

1 The Global Competitiveness Report 2012-2013. Full Data Edition. http://www3.weforum.org/docs/WEF_GlobalCompetitivenessReport_2012-13.pdf may differ, because these depend on the variations of each of the estimates offered by the respondents in the course of surveys. Thus, for example, Russia by the level of business sophistication was scored 3.3 and ranked $119^{\text {th }}$, and by the level of innovation, with a lower score of 3 , it came $85^{\text {th }}$. This means that, by comparison with business sophistication, many countries have even lower innovation scores.

We are now going to look more closely at Russia's competitiveness scores as demonstrated by the specific variables and their pillars ${ }^{2}$, on the basis of the latest Report. First, we will consider more favorable parameters. Evidently, by Russia's market volume, the ranking is high - it comes $7^{\text {th }}$. Then it comes $22^{\text {nd }}$ in terms of its macroeconomic situation, which is also not surprising given the Russian Federation's low level of government debt $\left(9^{\text {th }}\right)$ and the still favorable budget balance $\left(20^{\text {th }}\right)$; however, the inflation index (in per annum terms) places Russia only $111^{\text {th }}$. Then it comes $47^{\text {th }}$ by the level of infrastructure, and $136^{\text {th }}$ by the quality of motor roads - thus ranking amongst the most backward countries (with this variable being lowest among all the 113 variables -2.3 ). The situation with regard to railway infrastructure is better - Russia comes $30^{\text {th }}$; in terms of air transport infrastructure, Russia is $104^{\text {th }}$, although by the scale of passengers turnover of air transport (passenger traffic and mileage) it comes $12^{\text {th }}$; besides, Russia is at the top of the list by the number of cellular telephone users (coming $5^{\text {th }}$ ). A better score is achieved by Russia only in the field of malaria prevention, where this country tops the list. Russia is $52^{\text {th }}$ by the quality of higher education and training, but in terms of management quality in that sphere it comes $115^{\text {th }}$. Russia ranks relatively favorably $\left(57^{\text {th }}\right)-$ by its technological readiness level, although by the level of innovation, as noted earlier, it comes only $85^{\text {th }}$, with a very low score of 3.0. In terms of health and primary education this country ranks $65^{\text {th }}$ (the success achieved in malaria prevention notwithstanding), including $50^{\text {th }}$ by infant mortality, $62^{\text {th }}$ by primary education quality, and $100^{\text {th }}$ by life expectancy. Then Russia comes $84^{\text {th }}$ in terms of labor market flexibility and efficiency. The most remarkable feature in this connection is the high rate of employment of women where Russia ranks $38^{\text {th}}$; by the flexibility of wage determination it comes $65^{\text {th }}$, by the level of reliance on professional management $-110^{\text {th }}$, 'brain drain' $-111^{\text {th }}$, and cooperation in labor-employer relations - only $125^{\text {th }}$.

The worst situation can be observed in the following spheres: the level of business sophistication $-119^{\text {th }}$ the level of financial market development $-130^{\text {th }}$, the sophistication of the goods and services market -

2 For better emphasis, each pillar name is highlighted in bold italics, followed by some of the specific variables belonging to that pillar. 
$134^{\text {th }}$; and, sadly, in the sphere of institutions (institutional environment) Russia ranks only $133^{\text {th }}$. However, the low level of sophistication of the goods and services market is also determined in the main by institutional factors. Thus, by the intensity of local competition and effectiveness of antitrust policy Russia comes $124^{\text {th }}$; by the number of procedures needed to start a business $-97^{\text {th }}$, and by the number of days needed to open a business $-104^{\text {th }}$; by the extent and effect of taxation -121 th, by prevalence of trade barriers $132^{\text {th }}$, by customs procedures $-137^{\text {th }}$ (these indicators on the whole correlate well with Russia's previously considered other rankings). In terms of institutions proper, Russia went down from 110th in 2008 with a score of 3.3 to 133 rd in 2012 with a score of 3.1. The institutions are analyzed by 22 variables describing the most important features of the entrepreneurial environment. It is a well-known and long-established fact that the core feature of that environment in a market economy is the protection of property rights. Here we come $133^{\text {rd }}$, although in 2008 Russia's place was $122^{\text {nd }}$, and in $2009-121^{\text {st }}$. This issue is closely associated with that of independence of the judicial system, which is a guarantee of entrepreneurial right protection and where Russia ranks $122^{\text {nd }}$ with an extremely low score of 2.6, whereas in 2008 its ranking had been $109^{\text {th }}$. However, in 2011, when the score was the same, the ranking was a bit lower $-123^{\text {rd }}$. Both the progress and status of that indicator point to a very unfavorable situation. By the level of illegal payments and bribes Russia comes $120^{\text {th }}$ (vs. $115^{\text {th }}$ a year earlier). One of the variables is termed 'diversion of public funds', where Russia ranks $126^{\text {th }}$ with a score of 2.4 , which is below only that of the quality of motor roads (in 2008 it had ranked $\left.102^{\text {nd }}\right)$. Some variables determine the level of state administration. In terms of public trust of politicians, we come 86 th with a score as low as 2.5 , undue influence on official decisions $-127^{\text {th }}$, undue government spending - $103^{\text {rd }}$, the burden of government regulation procedures $-130^{\text {th }}$, government policy transparency $-124^{\text {th }}$, government services aimed at promoting business activity $-120^{\text {nd }}$. By the level of police efficiency in public safety protection Russia comes $133^{\text {rd }}$, in terms of the level of government infrastructure aimed at discussion promotion $-124^{\text {th }}$. The lowest ranking describes the level of protection of minority shareholders' interests $\left(140^{\text {th }}\right)$.

Although any ratings are to a certain degree arbitrary, and each of the ratings is based on its own specific methodology, the estimates of the different features of Russia's entrepreneurial climate are close enough and appear to be sufficiently reliable. When, for example, tax agencies present claims to taxpayers after the period of time allowed under a statute of limitations has expired and, in spite of the evident unlawfulness of such claims, the defendants lose their cases, or when corporate property is confiscated unlawfully with the help of power structures, the upshot is that the public starts to believe that it is dangerous to achieve success in business. When investigators and judges appropriate the right to determine, in conditions of a market economy, the so-called 'fair price', and any deviations from that price are interpreted as damages, and so the entire price of a transaction can be treated as material damage - this gives rise to arbitrary decisions on a broad scale, and almost any entrepreneur may fall victim to it. Under such conditions any private business unattached to government structures will feel unprotected, and so the business community loses trust and confidence in the authorities and in its own future prospects. The most natural response to such a situation is capital outflow and the flight of businesses abroad. Property protection issues and the law enforcement and judicial systems are currently experiencing a profound crisis, and this is a source of additional barriers in the way of doing business and using the country's economic potential. So, to solve the existing problems, it will not be enough to simplify the procedures - instead, it will be necessary to systematically work at improving the institutional environment itself, and this will take a lot of time. Otherwise, any ambitious hopes to succeed in upgrading Russia's Doing Business ranking will remain wishful thinking and a Fata Morgana.

The lack of self-confidence in the business community is further underlined by the lack of consistency in the government's regulatory acts. An especially vivid illustration is the sharp increase, in 2011, of the insurance contribution rate from 26 to $34 \%$ of the wages fund, with its subsequent lowering to $30 \%$. As noted RF Minister of Finance Anton Siluanov ${ }^{1}$, the State on the whole did not benefit from the raised insurance contribution rates - moreover, it even suffered some losses. However, in 2012 the rates of insurance contributions were increased for individual entrepreneurs, and the introduction of that measure was promptly followed by a dramatic decline in their number - resulting, most probably, from their flight into the shadow economy. The pension system is also undergoing reorganization - and even more changes are evidently to be expected in the future.

Some specialists believe that the Bank of Russia deliberately delayed its decision concerning the lowering of the refinancing rate as a signal aimed at boosting growth. However the fundamental factor determining the rise of that rate, as well as the level of interest

1 See an interview with him in Izvestia [The News], 7 March 2012, p. 5. 
rates in general, is rate of inflation. Interest rates on loans must be above the inflation rate, otherwise lending will be loss-making. And any responsible decisions with regard to lowering the refinancing rate (which, most probably, will soon be adopted and made public) can be possible only when it becomes clear which level of inflation will actually be achieved towards the year's end. Consequently, the principal condition for bringing down excessively high interest rates on loans, which can serve as a real obstacle to large-scale lending and thus eliminate one of the most important incentives for economic activity, is to suppress the inflation rate. However, so far only very modest success has been achieved in this direction.

As for politically biased approaches practiced by the authors of various rating systems, this consideration is true for Russia probably no more than, for example, for Kazakhstan. While Russia moved 11 spots down the list in World Economic Forum's Global Competitiveness Index, Kazakhstan over one year surged 21 points up from its former 72nd place (below Russia) with an index of 4.2 to $51^{\text {st }}$ place with an index of 4.4 . The estimate of that country's institutions significantly improved - by 28 points, and that of property protection - by 30 points. However, in the case of countries that cannot be perceived as models of democracy, one may reasons to wonder if such results were really achieved after the respondents, prior to participating in surveys, had been properly prepared to give the right answers. Such doubts become even more plausible when we consider the fact that in terms of the innovation index, which is less dependent on the results of surveys than the above indices, Kazakhstan not only demonstrated no progress at all, but moved down in its rank by one point. The index of economic freedom also somewhat declined, but in this particular sphere Kazakhstan is far ahead of Russia, being ranked 68th against Russia's 139th. However, if the changed estimates are caused by real achievements in the development of the institutional environment, Kazakhstan's experience may be especially interesting for us.

The current level of corruption in Russia is a very grave negative factor. The World Economic Forum's data demonstrate that corruption is perceived as the main obstacle to efficiently doing business, which was pointed out by $21 \%$ of respondents. This is a high level, and it is very illustrative, because only one answer could be picked out of the suggested list of answers. The second obstacle - low performance level of the central state apparatus - gained a little more than half of the votes by comparison with the first one (11.9\%). Thus it can be concluded that the situation with regard to corruption significantly depresses the development of business activity, even if the operating companies (whose representatives were selected as respondents) have found ways to adjust to it and shift the extra costs onto their clients.

The world's countries are scored on how corrupt their public sectors are seen to be by Transparency International, a global civil society organization leading the fight against corruption. In $2012^{1}$, the organization altered its methodology applied in scoring its Corruption Perceptions Index, and so that year's results are incomparable with those obtained for the previous years. The Index is based on a 0-100 score, where 0 means that a country is perceived as highly corrupt, and a 100 means that a country is perceived as very clean. The Index measures the perceived levels of public sector corruption 176 in countries and territories around the world. The ranking list is topped jointly by three 'cleanest' countries - Denmark, Finland and New Zealand, each with a score of 90. The worst score of 8 is assigned to Afghanistan, North Korea and Somalia, each ranked $174^{\text {th }}$. Russia is ranked $133^{\text {th }}$, with a score of $\mathbf{2 8 ,}$ which she shares with another six countries with similar scores. Among Russia's companions are Kazakhstan and Iran. The difference between the scores of 90 and 28 speaks for itself. In accordance with the previously applied methodology based on a 0-10 score, Russia enjoyed its best outlook for the preceding decade in 2004 with an index of 2.8, which then with some fluctuations began to decline to 2.1 in 2010, and then in 2011 again increased to 2.4, amounting to slightly more than $25 \%$ of its best previously achieved value. Thus, the level corruption in a given country is also considered to be one of the key factors undermining the confidence of companies in their prospects for doing business.

A typical feature of the last few years has been the revelation, on a large scale, and publication of the facts of corruption in various government structures. Until the first relevant court cases are completed and court verdicts pronounced, it is hard to decide if these activities reflect some genuine efforts to combat corruption. If the responsibility is placed only with a few selected 'scapegoats', these measures will be perceived by society only as an imitation of a true anti-corruption campaign. Of course, the public exposure of numerous existing facts may indeed be aimed at scaring the corrupt officials, who will then become aware that they, too, may be publicly exposed. Meanwhile, very often the consequences of such campaigns are reduced only to narrowing the range of people who are involved in bribing, while the amount of a bribe is further increased. Thus, according to the results of the Business Environment and Enterprise Performance Survey (BEEPS) conducted by the World Bank together

1 http://www.transparency.org/cpi2012/results 
with the European Bank for Reconstruction and Development (EBRD) in 2011, over the period from 2008 through 2011 in Russia, the number of respondents believing that corruption is no obstacle to doing business increased from 21 to $40 \%$. However, the companies that admitted to having given bribes, stated that the amount of a bribe over the same period increased from 4.6 to $7.3 \%$ of their annual sales! ${ }^{1}$

The economic results achieved over the past months of 2013 can be regarded as a vivid proof of the existing situation, where the current entrepreneurial climate not only prevents this country from taking full advantage of its development potential, but simply eliminates all its economic growth prospects. It seems that, instead of any serious efforts to improve the existing system, the authorities are hoping to boost growth by relying on government mega-projects - funded, among other things, from the National Welfare Fund. We mean here the recent decisions concerning the Moscow-Kazan Highway and the Central Ring Road construction projects, and the reconstruction of the East-Siberian Railway (Transsib). These projects will further increase the already excessive burden on government budget spending, in violation of the adopted budget rule, and push up the risks for this country's budget in the event of a drop in oil prices. It is difficult to believe that such projects have indeed been properly substantiated and subjected to expert's estimation. Judging by the past experiences, one can only be certain that the currently approved budgets for each project will prove to be insufficient, and that public funds will be grossly overspent - perhaps by several orders above the initially earmarked sum, the period of project implementation - extended well beyond the deadline, while the quality of work may be questionable. It is still too early to draw any conclusions as to whether these decisions will entail any rise, however slight (by $2.5 \%$ ), of the amount of investment in fixed assets in July 2013 on July 2012, while the cost of construction materials (production of all other non-metal mineral products) has increased by $4 \%$, and

1 http://slon.ru/economics/ebrr_vzyatki_v_rossii_stali_rezhe_ no_masshtabnee.913765.xhtml. construction costs - by $6.1 \%$, and whether this growth can indeed be relatively sustainable. Nevertheless, one must not overlook another factor - the very high pragmatism and adaptability of businesses, and their ability to develop not only under good conditions, but also - and in spite of - very unfavorable ones. Incidentally, according to data released by Rosstat, the inflow of foreign investment over the first half-year increased on the same period of last year by $32.1 \%$, and - most importantly - that of direct investment increased by $59.8 \%$. However, so far - and for a long time already any hopes for a stable rise in the level of investment demand and the overall dynamic of economic development have been futile. Besides, the decline in machine-building continues, and in some subsectors its rate has become significantly higher.

By of adding a spoonful of sugar to the medicine, as of 1 July the World Bank released its annual data on gross national income (GNI) per capita rankings for the previous year. Based on its GNI per capita, every economy is classified as low income ( $\$ 1,035$ and below); lower middle income $(\$ 1,036-4,085)$; upper middle income \$ 4,086-12,615); and high income (\$12,616 and above). Under the new classification, Russia has moved into the high income group - in other words, the group of wealthy countries. It seems that for Russia it will be important at least to keep that position, because some countries have moved in the opposite direction. Thus, for example, for Hungary the renewed classification means that she has been downgraded from her former place in the high income group. However, Russia - notwithstanding her current status in the World Bank's GNI per capita classification - falls behind in her growth rate by comparison with the global trends, and so other, formerly more backward, countries may begin to move ahead of Russia. So, once again, these results highlight the goal of a systemic transformation of the institutional environment and the creation of favorable conditions for doing business, which is decisive for preventing the downward movement of Russia's ranking in terms of economic development, and later on - for upgrading Russia's status in the world economy. 